\title{
Perancangan cetakan komponen holder sepeda motor dengan pendekatan metode elemen hingga
}

\author{
Andreas Hartoyo Yaputra, Sri Raharno, Yatna Yuwana Martawirya
}

Fakultas Teknik Mesin dan Dirgantara, Institut Teknologi Bandung Jl. Ganesha No. 10, Lb. Siliwangi, Coblong, Bandung, Jawa Barat 40132 Email korespondensi: harnos@ftmd.itb.ac.id

\begin{abstract}
Abstrak
Meskipun permodelan cetakan dengan pendekatan metode elemen hingga telah dikembangkan sejak akhir tahun 1970, namun sampai saat ini masih cukup banyak perusahaan manufaktur di Indonesia yang menggunakan metode konvensional trial and error dalam melakukan perancangan cetakan. Berdasarkan perspektif bisnis industri, metode trial and error berpotensi merugikan perusahaan dari sisi waktu dan biaya. Untuk itu dalam kajian ini telah dikembangkan permodelan perancangan cetakan dengan pendekatan analisis numerik yang dapat meminimalisasi kerugian waktu dan biaya. Dalam kajian ini akan digunakan studi kasus berupa komponen holder sepeda motor 600 cc dengan proses forging. Tujuan dari perancangan ini adalah untuk menentukan desain geometri cetakan yang sesuai sehingga material dapat mengisi secara penuh rongga cetakan, memperkirakan secara dini potensi kegagalan proses forging dan kapasitas mesin press yang diperlukan. Pada akhir kajian ini dapat ditentukan geometri cetakan dan parameternya, kapasitas mesin press yang dibutuhkan untuk melakukan proses forging, yaitu minimal sebesar 42 ton dan material cetakan dengan titik lebur di atas $863^{\circ} \mathrm{C}$ untuk mencegah kegagalan prematur.
\end{abstract}

Kata kunci: metode elemen hingga, holder sepeda motor, forging.

\begin{abstract}
Although mold modeling using finite element method has been developed since the late 1970s but the reality is still a lot of manufacturing companies in Indonesia are using the conventional method of trial and error in terms of making mold design. Based on industrial business perspective, the method of trial and error is very detrimental to the company because it takes a lot of time and expenses. Therefore this study has developed mold design modeling with numerical analysis approach to minimize process time dan cost losses. This research project uses a case study on motocyle 600 cc holder component with forging process. The purpose of this design is to determine the exact design of the mold so that the mold can be filled completely by material. In addition, to determine the tonnage required as well as a means of early detection of defects in this process. In the end of this research the geometry of mold and its parameter could be determined, requirement of press machine capacity determined at 42 tons. Furthermore, dies material needs to have melting point above $863^{\circ} \mathrm{C}$ to prevent premature failure.
\end{abstract}

Keywords: finite element method, motorcycle holder, forging.

\section{Pendahuluan}

Dewasa ini, banyak proses manufaktur yang telah dikembangkan untuk dapat memproduksi unit part baik dalam skala satuan maupun secara massal. Mulai dari proses casting, forging, stamping, drawing, dan masih banyak proses lainnya yang dapat digunakan untuk menghasilkan sebuah unit part dengan kualitas yang tinggi dan harga yang rendah. Salah satu proses yang kerap kali digunakan adalah proses forging. Proses forging merupakan proses pembentukan logam dengan aplikasi gaya kompresi yang tinggi. Melalui proses forging, butiran internal (internal grain) akan berdeformasi mengikuti bentuk dari cetakan sehingga secara umum dapat dikatakan proses forging lebih kuat dibandingkan proses casting maupun machining [1].

Sejak akhir tahun 1970, dimulai pengembangan simulasi proses forging menggunakan metode elemen hingga. Pada waktu itu, fitur automatic remeshing tidak tersedia sehingga dibutuhkan waktu cukup lama untuk menyelesaikan sebuah simulasi elemen hingga yang sederhana. Perkembangan pada saat ini sudah tercipta kemajuan teknologi komputasional untuk aplikasi perancangan proses di industri manufaktur dunia.

Namun secara umum masih cukup banyak industri manufaktur di Indonesia yang menggunakan metode perancangan trial and error. Berdasarkan perspektif bisnis industri tentu hal ini sangat merugikan perusahaan karena memakan banyak waktu dan biaya untuk melakukan proses perancangan secara trial and error sampai terbentuk desain yang sempurna. Untuk itu perlu dilakukan pengembangan perancangan dengan pendekatan analisis numeric [2].

Sesuai dengan perumusan masalah tersebut maka kajian ini bertujuan untuk menentukan geometri 
cetakan yang tepat serta berbagai parameternya dengan melakukan simulasi proses untuk memastikan cetakan terisi sempurna. Penentuan material cetakan yang sesuai untuk digunakan pada aplikasi inijuga diperlukan. Kemudian menentukan kapasitas mesin press yang dibutuhkan untuk proses forging sehingga kegagalan prematur pada cetakan dapat dihindari.

\section{Metode}

Holder merupakan salah satu komponen aksesoris kendaraan sepeda motor yang dibuat sebagai sarana untuk menyambungkan antara setang utama dan handle throttle. Selain itu holder juga berfungsi sebagai dudukan fitur elektronik seperti sakelar lampu, klakson, juga tombol starter.

Seperti pada Gambar 1, ditunjukkan gambar holder sepeda motor yang merupakan sarana penyambung antara setang utama dan handle throttle. Dengan melihat fungsinya yang beragam, baik sebagai sarana penyambung maupun sebagai dudukan fitur elektronik maka bentuk dari holder dapat dianggap cukup kompleks dan dibutuhkan tingkat kehandalan yang tinggi. Meski tidak mengalami tegangan yang cukup signifikan, tetapi apabila komponen ini mengalami kegagalan sewaktu-waktu dapat membahayakan jiwa dari pengendara karena pengendara dapat kehilangan kontrol dari sepeda motor yang sedang dikendarainya. Maka dari itu dalam proses manufaktur perlu dipertimbangkan tingkat kehandalannya karena terkait langsung dengan keselamatan jiwa dari pengendara.

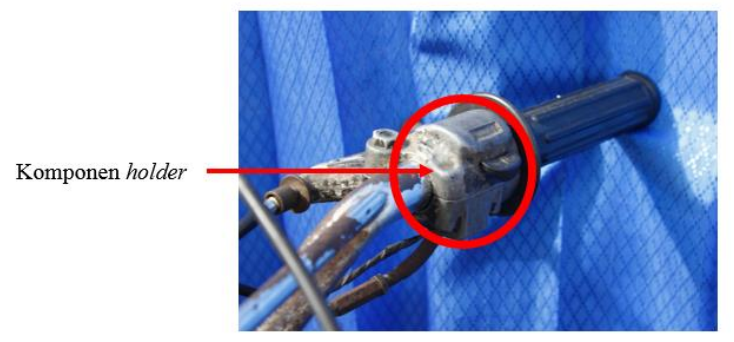

Gambar 1. Contoh komponen holder sepeda motor.

Dengan mengetahui fungsi komponen holder, pemilihan proses manufaktur dapat ditentukan secara baik. Proses manufaktur dapat dilakukan dengan beragam cara mulai dari metal casting, metal forming, shaping, hingga proses heat treatment. Untuk komponen holder ini, bentuk dari komponen termasuk kompleks sehingga proses manufaktur dengan machining tidak dapat dilakukan karena membutuhkan biaya yang besar dan waktu yang lama. Selain itu kapasitas produksi yang ditargetkan tiap bulannya mencapai 1000 unit, sehingga proses machining tidak akan dilakukan. Selanjutnya, proses manufaktur yang paling mungkin untuk dilakukan adalah casting dan forging [3]. Berikut adalah perbandingan proses casting dan forging dapat dilihat pada Tabel 1.
Tabel 1. Perbandingan proses casting dan forging.

\begin{tabular}{|c|c|c|}
\hline & Casting & Forging \\
\hline Lead time & Lebih lama & Lebih cepat \\
\hline Biaya & $\begin{array}{c}\text { Tidak fleksibel } \\
\text { (hanya untuk } \\
\text { produksi massal) }\end{array}$ & Fleksibel \\
\hline Potensi cacat & Lebih kecil & Lebih besar \\
\hline Sifat mekanik & $\begin{array}{c}\text { Tingkat kekuatan } \\
\text { rendah }\end{array}$ & $\begin{array}{l}\text { Tingkat } \\
\text { kekuatan } \\
\text { tinggi }\end{array}$ \\
\hline $\begin{array}{l}\text { Perlakuan } \\
\text { permukaan }\end{array}$ & Lebih kasar & $\begin{array}{l}\text { Lebih halus } \\
\text { karena ada } \\
\text { deformasi } \\
\text { plastis pada } \\
\text { permukaan }\end{array}$ \\
\hline $\begin{array}{c}\text { Tingkat } \\
\text { keandalam }\end{array}$ & Lebih rendah & Lebih tinggi \\
\hline $\begin{array}{c}\text { Respon } \\
\text { terhadap } \\
\text { perlakuan panas }\end{array}$ & $\begin{array}{l}\text { Dibutuhkan } \\
\text { kontrol yang } \\
\text { tinggi }\end{array}$ & $\begin{array}{c}\text { Tidak } \\
\text { dibutuhkan } \\
\text { kontrol yang } \\
\text { tinggi }\end{array}$ \\
\hline Variasi material & Lebih sedikit & Lebih banyak \\
\hline
\end{tabular}

Seperti diperlihatkan pada Tabel 1, proses casting akan memakan waktu lebih lama dibanding forging karena rentang temperatur yang tinggi sehingga membutuhkan waktu yang lama untuk proses pendinginan [4]. Selanjutnya dari segi biaya, proses casting memiliki rentang harga yang sempit sehingga hanya dikhususkan untuk produksi massal. Setelah produk selesai dibuat, produk dari hasil forging tidak perlu dilakukan perlakuan permukaan karena permukaannya sudah cukup halus apabila dibandingkan dengan casting karena terjadinya deformasi plastis. Apabila ditinjau dari tingkat kekuatan, proses forging memiliki tingkat kekuatan yang lebih tinggi dibanding casting, sebab mengalami tekanan yang cukup tinggi sehingga dapat dikatakan proses forging memiliki tingkat keandalan yang lebih tinggi. Pada sisi yang lain potensi kemungkinan timbul cacat pada proses forging lebih besar dibanding casting yaitu seperti lapping dan porositas [5].

Ditinjau dari respon perlakuan panas, untuk proses casting dibutuhkan kontrol yang tinggi sebab diperlukan ketepatan untuk memperkirakan temperatur atas dari proses ini. Apabila temperatur proses yang dilakukan melebihi temperatur yang seharusnya maka diperlukan waktu yang cukup lama untuk mendinginkan material [6]. Selanjutnya untuk proses forging tidak diperlukan kontrol temperatur yang cukup tinggi sebab rentang temperatur untuk proses ini tidak setinggi proses casting. 
Berdasarkan berbagai pertimbangan tersebut, maka komponen holder lebih cocok untuk diproduksi dengan proses forging. Dilihat dari segi keandalan, proses forging akan menghasilkan produk dengan tingkat kekuatan yang lebih tinggi karena adanya deformasi plastis. Ditambah lagi dengan waktu proses yang relatif lebih cepat dibanding proses casting sehingga dapat menghasilkan produk lebih banyak dalam waktu yang sama. Pada bagian berikut ini akan dibahas mengenai proses perancangan cetakan holder dengan menggunakan simulasi metode elemen hingga [7].

Setelah mengetahui fungsi komponen holder maka dapat ditentukan proses manufaktur yang tepat untuk memproduksi komponen ini secara massal yaitu dengan proses forging [6]. Pada bab ini akan dibahas mengenai langkah-langkah perancangan cetakan holder dengan menggunakan simulasi metode elemen hingga. Proses permodelan yang dilakukan yaitu permodelan part dan selanjutnya dilakukan permodelan cetakan. Untuk permodelan komponen, dilakukan dengan sumber yang berasal dari gambar teknik. Selanjutnya dilakukan proses pemodelan secara manual dengan bantuan software CAD. Gambar 3D komponen ini ditunjukkan pada Gambar 1 berikut ini.

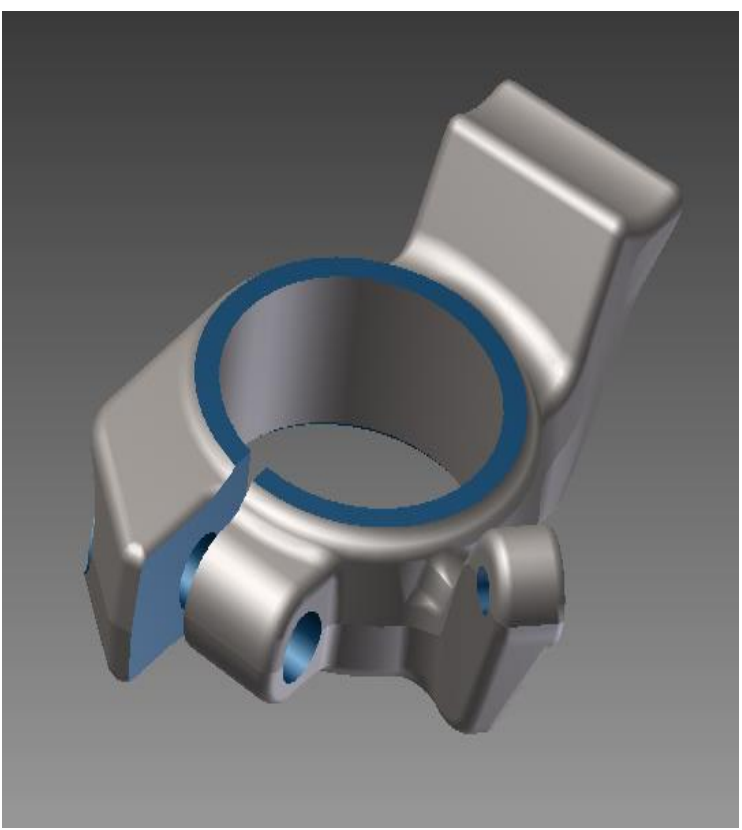

Gambar 1. Model 3D komponen holder (produk akhir).

Untuk permodelan selanjutnya adalah permodelan cetakan, ada beberapa bagian dari komponen yang harus dimodifikasi. Modifikasi dari komponen ini perlu dilakukan karena penyesuaian dengan batasan kemampuan dari proses forging untuk mencapai pembuatan komponen tersebut. Selanjutnya perlu dilakukan proses finishing untuk mencapai bentuk akhir yang diinginkan. Proses finishing yang perlu dilakukan antara lain, boring, grinding, dan slotting. Beberapa modifikasi yang dilakukan pada komponen ditunjukkan Tabel 2. Setelah dilakukan permodelan komponen, langkah selanjutnya ialah memodelkan cetakan. Permodelan cetakan ini merupakan iterasi rancangan awal yang digunakan sebelum selanjutnya dilakukan proses modifikasi lanjut.

Tabel 2. Proses modifikasi permodelan komponen.

\begin{tabular}{|c|c|c|}
\hline $\begin{array}{c}\text { Jenis } \\
\text { Modifik } \\
\text { asi } \\
\end{array}$ & $\begin{array}{c}\text { Komponen } \\
\text { Awal }\end{array}$ & $\begin{array}{l}\text { Komponen } \\
\text { setelah } \\
\text { Modifikasi }\end{array}$ \\
\hline $\begin{array}{c}\text { Ekstrusi } \\
\text { lubang } \\
\text { utama }\end{array}$ & & \\
\hline $\begin{array}{l}\text { Ekstrusi } \\
\text { lubang } \\
\text { minor } 1\end{array}$ & & \\
\hline $\begin{array}{l}\text { Ekstrusi } \\
\text { lubang } \\
\text { minor } 2\end{array}$ & & \\
\hline $\begin{array}{l}\text { Ekstrusi } \\
\text { lubang } \\
\text { minor } 3\end{array}$ & & \\
\hline $\begin{array}{c}\text { Ekstrusi } \\
\text { sambung } \\
\text { an baut }\end{array}$ & & \\
\hline
\end{tabular}

Permodelan cetakan ini dilakukan berdasarkan komponen yang telah dimodelkan sebelumnya. Pada proses permodelan cetakan, terlebih dahulu harus ditentukan batas pemisah antara cetakan atas dan bawah pada komponen yang disebut parting line.

Pada Gambar 2 dapat dilihat gambar permodelan komponen dengan warna merah dan hijau. Warna tersebut menunjukkan batas parting line atau pemisah antara cetakan atas dan bawah. Warna hijau menunjukkan porsi cetakan atas dan warna merah menunjukkan porsi cetakan bawah. Garis pertemuan antara warna merah dan hijau disebut parting line. Garis ini merupakan tempat bertemunya antara cetakan atas dan bawah [5]. Dalam penentuan posisi parting line ini, diusahakan volume komponen dibagi sama rata 50:50, sehingga memudahkan material untuk mengalir mengisi rongga cetakan. Proses penentuan parting line sendiri dapat dilakukan secara manual maupun secara otomatis dengan 
menggunakan fitur draft analysis. Kebanyakan software CAD sudah dilengkapi dengan fitur draft analysis sehingga fitur ini memudahkan penggunanya untuk menentukan posisi parting line dengan mudah dan cepat.

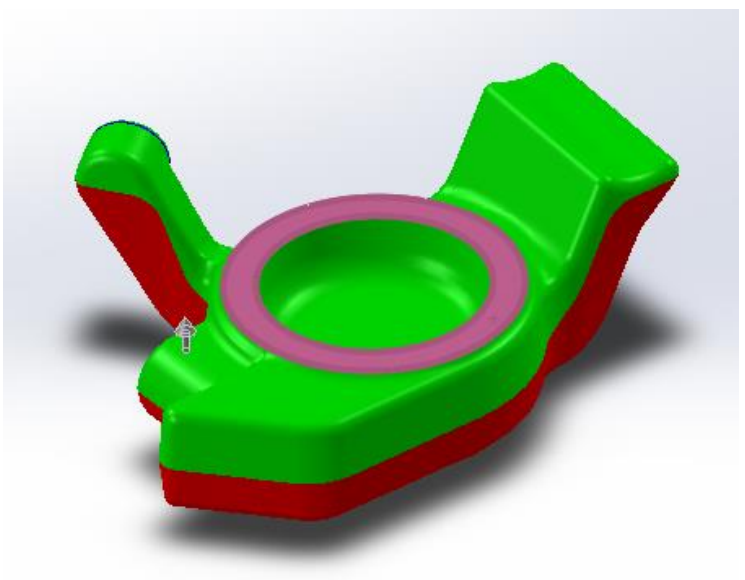

Gambar 2. Permodelan komponen holder dengan parting line.

\section{Hasil dan Pembahasan}

Setelah melalui proses perancangan cetakan, kemudian dilakukan beberapa iterasi untuk mendapatkan nilai dari beberapa parameter yang dibutuhkan. Proses iterasi penting untuk dilakukan karena flash yang terbentuk pada proses forging tidak dapat ditentukan secara matematis melainkan diperlukan simulasi secara numerik. Berdasarkan Gambar 3, produk holder terbentuk secara sempurna. Pada simulasi tahap akhir ini dilakukan penambahan volume billet dibanding simulasi tahap kedua. Volume billet yang digunakan pada simulasi tahap akhir ini sebesar $66434 \mathrm{~mm}^{3}$ sedangkan volume dari komponen holder sebesar $46240 \mathrm{~mm}^{3}$.

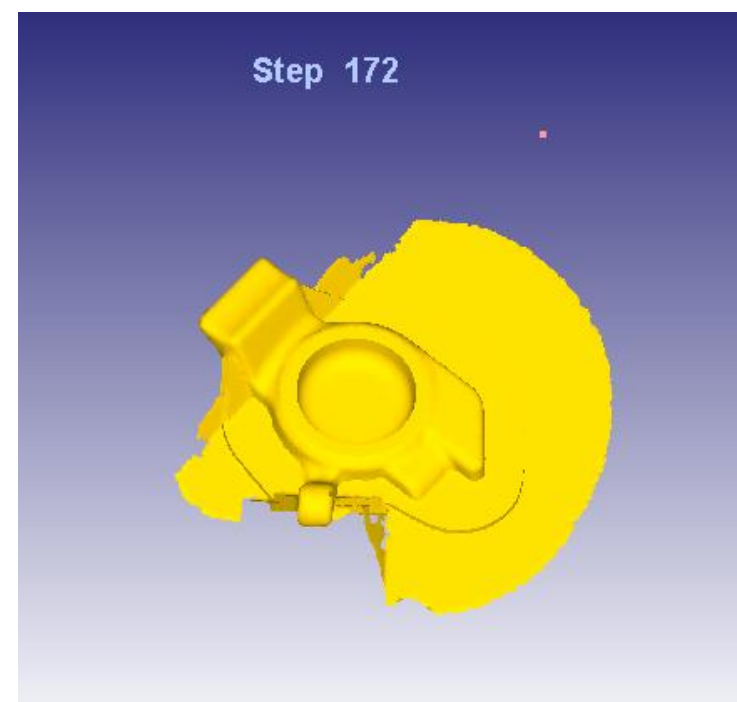

Gambar 3. Hasil simulasi tahap akhir.

Dari hasil analisis diperoleh nilai tegangan maksimum pada komponen sebesar $1530 \mathrm{MPa}$. Tegangan maksimum berada pada daerah sekitar kanal. Hal ini terjadi karena masih ada beberapa flash yang keluar dari area kanal. Meskipun demikian, secara keseluruhan komponen holder memiliki tegangan yang rendah karena mayoritas berwarna biru dengan rentang antara 511-1020 MPa. Tegangan maksimum yang terjadi pada kajian ini hanya bersifat tegangan lokal dan hanya terletak pada permukaan komponen sehingga tegangan maksimum tersebut dapat diabaikan. Selanjutnya, karena tegangan yang terjadi masih berada sedikit di atas kekuatan tegangan maksimum dari material AISI 1015, sehingga pada daerah yang ditunjukkan warna hijau dapat dilakukan sedikit pelumasan untuk mengurangi tegangan yang terjadi pada saat kompresi. Distribusi tegangan pada komponen secara lengkap dapat dilihat pada Gambar 4.

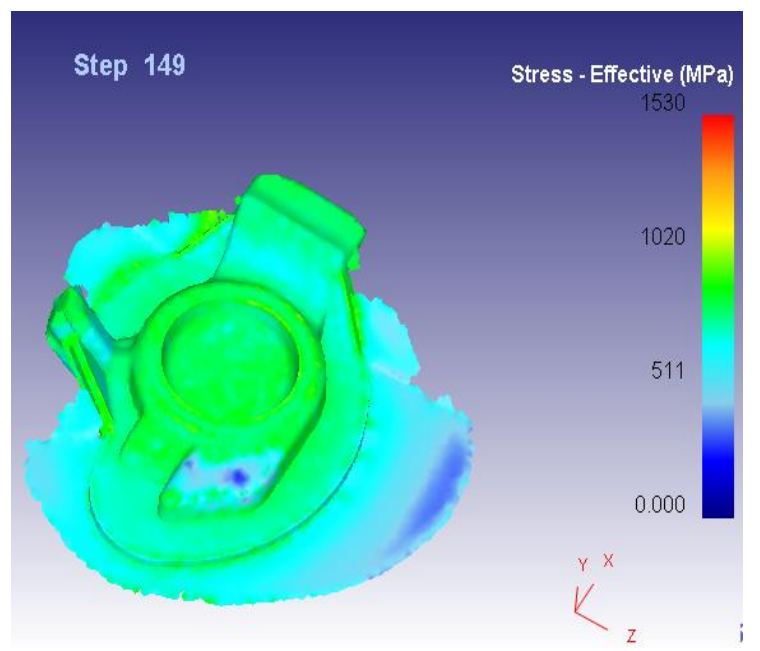

Gambar 4. Distribusi tegangan pada komponen.

Selanjutnya, temperatur maksimum komponen sebesar $1280^{\circ} \mathrm{C}$. Temperatur maksimal terjadi pada daerah sekitar kanal karena pada daerah ini mengalami kompresi yang tinggi. Tetapi, perlu diperhatikan bahwa mayoritas temperatur berkisar antara $445-863^{\circ} \mathrm{C}$. Untuk itu dalam proses penentuan material cetakan perlu diperhatikan untuk memilih material dengan titik lebur di atas $863^{\circ} \mathrm{C}$ atau dapat juga diatasi dengan melakukan proses perlakuan panas sebelumnya. Material cetakan yang dapat digunakan untuk produksi komponen holder ini dapat menggunakan baja karbon tinggi. Distribusi

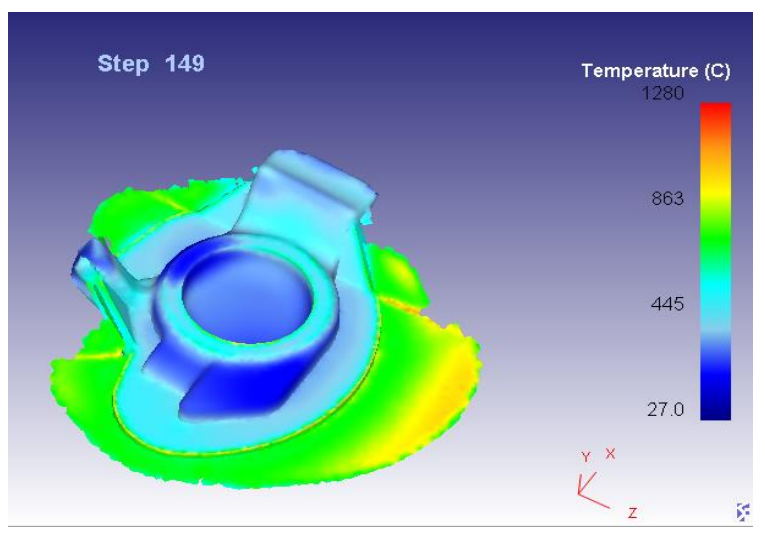


temperatur pada komponen diperlihatkan pada Gambar 5.

Gambar 5. Distribusi temperatur pada komponen.

Langkah terakhir dari kajian ini adalah menentukan besar tonase yang diperlukan untuk melakukan proses forging komponen holder. Dengan menggunakan fitur dari perangkat lunak didapat kurva beban berbanding besar stroke yang ditunjukkan pada Gambar 6.

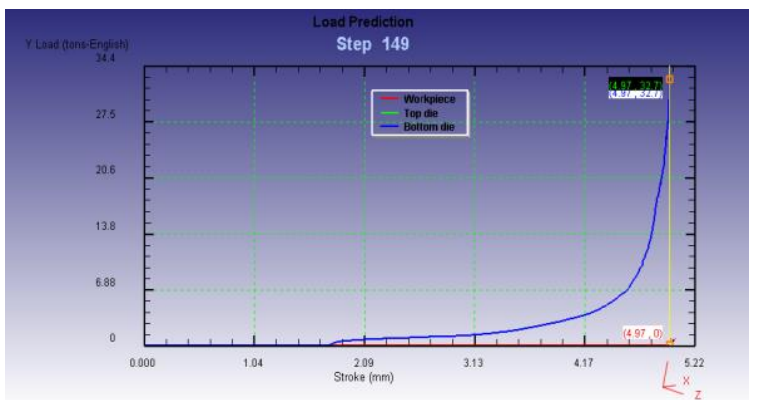

Gambar 6. Kurva beban berbanding stroke selama proses forging komponen holder.

Gambar 6 menunjukkan kurva beban berbanding stroke selama proses forging komponen holder. Kurva tersebut berbentuk linier mulai dari stroke 0 mm sampai dengan $5 \mathrm{~mm}$. Hal ini disebabkan karena beban yang dibutuhkan sebanding dengan energi yang dibutuhkan material untuk mengalami deformasi tahap awal. Kemudian kurva tersebut berbentuk kuadratik pada stroke $5 \mathrm{~mm}$ hal ini disebabkan karena material mulai berdeformasi memenuhi ronggarongga ujung sampai akhirnya material tidak dapat berdeformasi lagi. Untuk mendapatkan hasil yang valid maka nilai yang diambil adalah saat kurva akan bergerak memotong axis pada stroke $5 \mathrm{~mm}$ yaitu dengan besar tonase sebesar 20,6 ton. Sehingga untuk melakukan proses forging komponen holder ini diperlukan mesin press dengan kapasitas minimal 42 ton karena dihasilkan dua produk holder dalam sekali langkah penuh.

\section{Kesimpulan}

Kajian ini menghasilkan kesimpulan bahwa geometri cetakan dan berbagai parameternya sudah ditentukan dengan menggunakan simulasi proses. Rasio flash yang dihasilkan pada proses kajian ini sebesar 46,17\%. Material cetakan yang dapat digunakan untuk proses forging komponen holder ini harus memiliki titik lebur di atas $863^{\circ} \mathrm{C}$ untuk menghindari adanya kerusakan prematur pada cetakan. Kapasitas mesin press yang harus digunakan untuk melakukan proses ini minimal sebesar 42 ton.

\section{Daftar Pustaka}

[1] S. Kalpakjian dan S. Schmid. 2006, Manufacturing Engineering and Technology, Pearson Education South Asia Pte Ltd., Singapore.
[2] Murjito, ST. MT. 2007, Pengembangan Model Perancangan Proses Forging Dengan Menggunakan program Ansys Untuk Mencegah Kegagalan Produk, Universitas Muhammadiyah Malang, Malang.

[3] T. Altan dan M. Shirgaokar. 1994, Process Design in Impression Die Forging. NSM Laboratory, Ohio State University.

[4] R. Radev and B. Tomov. 1999, Preform Design in Hot Die Forging, Department of Materials and Processing Technology University of Rousse 8 Studentska St., 7017 Rousse, Bulgaria.

[5] F. R. Biglari, N. P. O'Dowd and R. T. Fenner. 2003, Optimum Design of Forging Dies using the Finite Element Method, Mechanical Engineering Department, Imperial College of Science, Technology and Medicine, London SW7 2BX, UK.

[6] Siamak Abachi. 2004, Wear Analysis of Hot Forging Dies, The Graduate School Of Natural and Applied Sciences of the Middle East Technical University.

[7] Toshiaki Tanaka, Koukichi Nakanishi, Yasuhiro Yogo, etc. 2006, Prediction of Hot Forging Die Life Using Wear and Cooling Model, Research Report. 